\title{
Belâgat İlmindeki Mecâz-Kinâye Kavramlarının Fıkhî Hükümlere Etkisi
}

\author{
Hafsa KESGIN ${ }^{1}$
}

\section{Özet}

Beyân ilmi çerçevesinde özellikle lafza yüklenen anlamı ortaya koyan dil kuralları belâgat ilminde olduğu kadar lafız-mana çerçevesinde gelişen fikıh usulünde de önem taşır. Bu sebeple fakih ve usulcüler lafız-mana ilişkisini ortaya koymayı hedefleyen dil tartışmalarına lafzın manaya delâleti kapsamında genişçe yer vermişlerdir. Lafzın manaya delâleti esasen hüküm istinbâtında önemli olduğundan lafzın hükme delaleti, söyleyenin niyetinin veya sözün söylenmiş olmasının tek başına hüküm doğurması gibi lafız tartışmaları fikıh usûlünün bölümlerinden birini teşkil etmiştir. Diğer taraftan söz konusu bu lafizlardan olan mecâz ve kinâye kavramları belâgat ve fikıh ilminde lugavî ve fikhî ihtilafların kaynağı olmuşlardır. Biz bu çalışmada, fukahânın bu kavramlara olan farklı yaklaşımlarının fikhî hükümlere olan etkisi üzerinde duracağız.

Anahtar Kelimeler: F1kıh, Belâgat, Mecâz, Kinâye

\section{The Concepts Of Majaz and Kinâyah In Eloquence Effect To The Provisions Of Fiqh}

\begin{abstract}
The rules of language that reveals especially the literal meaning attributed are important in the framework of the science Beyan. Also, these rules are important not only in the sicence of Eloquence (Belağat) but also in the Principles of Islamic Jurisprudence (Usul al-F1kh) developing in the axis of the wording and meaning. For this reason, the scholars of Islamic Jurispuridence (F1qh) and Principles of Islamic Jurisprudence (Usul al-F1kh) give a large area for language discussions that aim to reveal the relationship between wording and meaning in terms of indicating the meaning of the wording in their works. It is substantially important that the wording indicates the meaning in the identifing the provisions.
\end{abstract}

1 Dr., Temel İslam Bilimleri İslam Hukuku Anabilim Dalı, hafsasenses@hotmail.com. 


\section{$258 \cdot$ YALOVA SOSYAL BILIMLER DERGISI}

Therefore, language discussions constitute one of the parts of the Principles of Islamic Jurisprudence (Usul al-F1kh) about which the wording indicates the provisions and the intention of the person saying the wording, or the wording said reveals alone the provisions. On the other hand, the majaz and kinâyah that are from the wordings mentioned above have also been a source of conflicts about denotation and Islamic Jurisprudence in the science of Islamic Jurisprudence (F1qh) and science of Eloquence (Belagat). In this study, the different approaches to the concept of the scholars of Islamic Jurispuridence will focus on the effect of provisions.

Keywords: Fiqh, Eloquence (Belağat), Majaz, Kinâyah

\section{Giriş}

Arap dilinde bazı lafızlar kullanıldıkları yere, kullanıcıya, kullanıcının amacına göre farklı anlamlar ihtiva edecek şekilde işletilmiştir. Arapça'nın dil mantığ1 ve zengin dil özelliklerinin de etkisiyle Araplar»ın günlük hayatında ve hukuki işlerinde mecâzî ve kinayeli lafızlar sıkça kullanılmış bunun sonucunda da bugünkü hukuk dilinde ifadelendirilen terimler ortaya çıkmıştır.

Dini metinlerin temel ifadeleri olan söz konusu lafızların anlamlarının tesbitinde ne ölçüde niyete ya da rızaya itibar edileceğine ilişkin tartışmalar klasik usul ve furû' kitaplarında geniş bir şekilde yer işgal etmiştir. Ancak fikıh usûlünün anlama faaliyetlerinin temelini oluşturan bu zengin birikim, kelimelerin örfteki kullanımlarını esas alarak geliştirildiği ve hukukta objektifliği ve istikrarı sağlamaya matuf birtakım kurallara bağlanmaya çalışıldığı için konu esasen dil biliminin alanına girmekte, bu konuda öncelikle dil bilimi kurallarına başvurulmasını gerektirmektedir. $\mathrm{Bu}$ bağlamda her dilin yapısı, mecâz ve kinayelerin kullanımı, anlamları ve bölümleri birbirinden farklı olacağından mecâzî ve kinâyî lafızların manaya delaleti konusunun her bir dilde o dilin kuralları içinde ele alınması, fikhî çözümlerin de bu verilerin üzerine oturtulması gerekir. ${ }^{1}$

1 Koca, Ferhat, "Kinaye", DIA, 2002, XXVI, 37.

YIL: 6 SAYI: 11 
Mecâz ve kinâye kavramları, Arap belâgatının bir kolu olan beyân ilminin konusunu oluştururken fikıh usûlü ilminde lafız bahisleri başlığ altında işlenmektedir. Fıkhın asli kaynaklarından olan Kitâb’ın Arapça olması Arap dilinde önemli olan bu kavramları fıkıh ilmi için de aynı derecede önemli hale getirmiştir. Zira mecâz ve kinâye ihtiva eden âyetler bir takım ihtilâflara konu olmuştur. Söz konusu bu ihtilaflar sadece fikıh ilmi değil Arap diline ve Kitâb'a dayanan bütün ilimler için geçerlidir. ${ }^{2}$

Biz bu çalışmamızda, öncelikle mecâz ve kinâye kavramlarının belâgat ilmindeki anlam çerçevesini genel olarak ele aldıktan sonra bu kavramların Fıkıh ilmindeki karşılığını ve fikhî hükümlere olan etkilerini inceleyeceğiz.

\section{Belâgat İlminde Hakîkât ve Mecâz Kavramları}

Belâgat ilmi bu iki kavramı, bir anlamı değişik şekillerde ifade etmenin yollarını belirleyen beyân ilmi kapsamında ele almıştır. Beyân, kişiye bir manayı farklı şekillerde ifade edip derdini iyi anlatabilme yetisi kazandırır. ${ }^{3}$ İfadeyi kullanan kişi, anlamı güçlendirmek, pekiştirmek veya daha açı ifade etmek için teşbih, mecâz, istiâre ve kinâye sanatlarından yararlanır. ${ }^{4}$ Söz konusu bu ayrımın ilk halkasını hakîkât ve mecâz kavramları oluşturur. Ancak bu ilimde temel olan iki asıl öncelikle mecâz ve kinâye lafızlarıdır. Zira dilcilerin tamamı mecâzın hakikatten kinâyenin de tasrîhten daha beliğ olduğu konusunda icmâ etmişlerdir. ${ }^{5}$ Bu bağlamda mecâz kavramını anlamak için hakikât kavramına kinâye kavramının anlaşılması için de sarîh kavramına ihtiyaç vardır. Bu sebeple hakîkât kavramı mecâz başlı̆̆ı altında sarîh kavramı ise kinâye başlığı altında beyân

2 Kur'an'da mecâzın varlığı problemiyle ilgili İslam âlimlerinin tartışmaları ve delilleri hakkında daha geniş bilgi için bkz. Akdemir, Hikmet, “Kur'an-1 Kerîm'de Mecâzın Varlığı Problemi”, Harran Üniversitesi Illahiyat Fakültesi Dergisi, Şanlıurfa, 1998, sy. 4, s. 59-90.

3 Molla Cîven, Ebî Sa'id, Nûru'l-envâr ale'l-menâr, İstanbul, 1986, I, 155; Kablan, Süleyman, Arap dili ve Belâgatında Mecaz-ı Mürsel ve Alakaları(Yüksek Lisans Tezi), İstanbul, 2006, s. 19-21.

4 Müftüoğlu, Nasrullah, "Beyân”, Dİ, 1992, VI, 22.

5 Cürcânî, Abdulkâhir, Delâilü'l-i'caz, D1meşk, 1987, s. 113. 
ilminin konuları arasında değerlendirilir. ${ }^{6}$ Beyân ilminin amacı ise, edebi metinleri iyi anlayabilmektir. Biz burada beyân ilmi çerçevesinde ele al1nan bu kavramların belâgat ilmindeki manaları üzerinde duracağız. Bu amaçla öncelikli olarak hakîkât kavramının Arap dilindeki terim manasını konu alacağız.

Hem fikıh hem de belâgat terimlerini ele aldığı eserinde Cürcânî (ö. 816) hakîkât lafzını, "kelimenin konulduğu manada kullanılmasıdır" şeklinde tanımlamıştır. ${ }^{7}$ Mesela "eli uzun" kavramı kullanıldığında, örften kaynaklanan bir anlam yüklemesi sonucunda "cömertlik" değil bizatihi kişinin elinin uzunluğunun kastedilmiştir. Hakikatin luğavî, örfî ve şer'i olmak üzere türleri vardır.

Luğavî Hakîkât: Lafzın konulduğu luğavî manada kullanılmasıdır. Diğer bir ifadeyle lafzın anlamının bizâtihi luğatı va'z eden tarafından koyulmasıdır. Güneş, ay, yıldızlar gibi kavramlar buna örnek verilebilir.

Şer'i Hakîkât: Lafzın kullanıldığı anlamın Şârî' tarafından tayin edilmesidir. Salât, zekât gibi kullanılan kavramların luğavî manası farklı olsa da bizâtihi Şârî' tarafindan farklı anlamlarda terimleștirilerek va'z edilmiştir. Yine fikıh ilmine özel kullanılan talak, muhâlâ, hûl gibi kavramların bu ilim içinde terimleştirilmesi bu kabil bir işlemdir.

Örfì Hakîkât: Örfün bir lafzı belli bir mana için tayin etmesidir. Bu bazen herkesin kullandığı manada olabildiği (umumî örf) gibi bazen de belli meslek gruplarının kendi aralarında kullandıkları lafızlar (hususî örf) olabilir. $^{8}$

Mecâz kavramı, hakikât kavramının zıddı olarak tanımlanmaktadır. Yani bir lafzın aralarındaki alâkadan dolayı konulduğu mananın dışında kullanılmasını ifade eder. ${ }^{9}$ Son dönem dilcilerden Hatib el-Kazvînî’ye (ö. 739) göre mecâz, "aralarında bir ilişkiden dolayı kelimenin konulduğu

6 Örnek olarak bkz. Hâşimî, es-Seyyid Ahmed, Cevahiru'l-belağa fi'l-meani ve'l- beyan ve'l -bedi', (tah. Yûsuf es-Samîlî), Beyrut, ts..

7 Cürcânî, Mu'cemu't-ta'rifât, (tah. Muhammed Siddîk el-Minşâvî), Kâhire, ts., s. 79.

8 Özdemir, İbrahim, İslam Düşüncesinde Dil ve Varlık, İstanbul 2006, 44-5.

9 Cürcânî, et-Ta'rifât, s. 111.

YIL: 6 SAYI: 11 
anlamın dışında kullanılmasıdır". ${ }^{10}$ Meselâ, hicret eden Hz. Peygamber (s.a.v.) Medine'ye ulaştığında halkın “üzerimize dolunay doğdu” şeklindeki sözlerinde mecâz vardır. Burada dolunay hakikî mânâsında kullanılmamıştır. Çünkü kastedilen, gökteki ay değildir. Dolunayın, hakikî mânâsına yani gökteki ay olarak anlaşılmasına mâni karîne ise "veda tepeleri" ifadesidir. Buradaki dolunaydan kastedilen mana veda tepeleri karînesinden dolayı Hz. Peygamber (s.a.v.)' dir. Arap dilinde her mecâz lafız için mutlaka bir alâkâ söz konusudur. Zirâ Araplar iki mana arasında bir münâsebet varsa kelimeyi mecâz manasından başka manaya göndermezler. ${ }^{11}$ Mecâz kavramının tanımının anlaşılması için alâkâ ve karîne kavramlarının da tanımlanması gerekir.

Alaka: Hakîkî mana ile mecâzî mana arasındaki münasebettir. Bu münasebetle iki mana birbirine bağlanır ve zihin birincisinden ikincisine intikal eder. $^{12}$

Karîne: Sözü söyleyen kişinin, sözü hakîkî manasında kullanmad1ğına delil olarak getirdiği şeydir. Bu delil bizzat sözü söyleyenin telaffuz ettiği ifade içinde yer alırsa "lâfzî karine"”'adını alır. İfadenin içinde yer almıyorsa sözü söyleyen kişinin halinden veya sözün gelişinden anlaşıllyor ise "halî karîne" adını alır. ${ }^{13}$

\section{A. Mecâzın Çeşitleri}

Mecâz, dilcilere göre farklı farklı çeşitlendirilmiştir. Meselâ, mecâzı, kendisinde bir alâkanın varlığı ve yokluğu bakımından mecâz-1 lugâvî ve mecâz-1 aklî̀ ${ }^{14}$ diye ikiye ayıran dilciler yanında mecâzı, aklî mecâz ve mecâz-1 mürsel, mecâz1- mürseli de müfred mürsel, müfred bi'l-istiâre, mürekkeb mürsel ve mürekkeb bi'l-istiâre şeklinde ayıran dilciler vardır. ${ }^{15}$ Lugâvî mecâz da kendi içinde mecâz-i mürsel ve istiâre şeklinde ayrıl-

10 Kazvînî, Hatîp, el-Îzâh fí 'ulûmi'l-belâga, (nşr. İbrâhîm Şemsüddîn), Beyrut, 2003, s. 202203.

11 Ali el-Cârim, Mustafa Emin, Belâgatu'l-vâdıhâ, İstanbul, ts., s. 109.

12 Hâşimî, Cevâhiru'l-belâga, s. 251; Akdemir, Hikmet, Belağat Terimleri Ansiklopedisi, İzmir, 1999, s. 231; Ali el-Cârim, Mustafa Emin, Belâgatu l-vâzıha, s. 70.

13 Hâşimî, Cevâhiru'l-belâga, s. 251; Ali el-Cârim, Mustafa Emin, Belâgatu'l-vâdıhâ, s. 70.

14 Ali el-Cârim, Mustafa Emin, Belâgatu l-vâdıha, İstanbul, ts., s. 69-122.

15 Hâş̧imî, Cevâhiru'l-belâga, s. 251. 
maktadır.

Müfred Mecâz: Mecâz-1 mürekkebin zıddıdır. Mecâzın bir terkipte değil de tek bir kelimede meydana gelmesidir. Alâka, cesur bir adama aslan denmesinde olduğu gibi müşâbehet olursa "müfred mecaz", müşâbehetin dişında bir alâka söz konusu olursa "müfred mecaz-1 mürsel” ortaya çıkar. Meselâ "Kureyş’e sor” ifadesinde Kureyş kabilesi kastedilir, aradaki alakâ ise "umûm-husûs" alâkası olduğundan müfred mecaz-1 mürsel örneklerinden birisi olarak zikredilebilir. ${ }^{16}$

Şer'i Mecâz: Bir lafzın şer'i manasının dışında bir mana için kullanılmasıdır. Salât kelimesinin şer'i manası "namaz" iken dua manasında kullanılması şer'i mecaz olur. ${ }^{17}$

Örfi Mecâz: Örfte hakiki manasıyla bilinen bir lafzı bu mananın d1şında kullanmaktır. Nahiv örfünde fiil, malum kelime çeşitlerinden biri iken "iş-eylem” manasında kullanılması örfî hâs olan mecâzı teşkil eder. Umumî örfte, yerde yürüyen hayvanlar için kullanılan "dâbbe" kelimesinin insan için kullanılması ise adı verilen mecâzı oluşturur. ${ }^{18}$

Aklî Mecâz: Aklî mecâz dilbilimciler tarafından üzerinde en fazla tartışmanın olduğu mecâz türlerinden biridir. ${ }^{19}$ Belâgat lugatlarında "bir fiili veya fiil manasına gelen ismi, kendi failine hakîkî isnadına engel olan bir karine bulunmak şartıyla bir ilgi yüzünden konuşana göre gerçek failinden başkasına isnat etmektir ${ }^{20}$ şeklinde tanımlanırken, Cürcânî (ö. 471), "kendisiyle ifade edilen hükmün bir tür tevil ile akla aykırı olarak getirildiği her cümledir" 21 şeklinde tanımlamıştır. Kazvinî, "fiilin veya fiil manalı kelimenin kendisine ait olmadığı, ancak kendisiyle ilişkili şeye tevil yoluyla isnadıdır"22 şeklinde ifade etmiştir. Cürcânî burada akla aykırı hususuna vurgu yapmıştır ancak Kazvinî’nin böyle bir vurgusu mevzu bahis değildir.

16 Akdemir, Belâgat, s. 231; Hâşimî, Cevâhiru'l-belâga, s. 252.

17 Akdemir, Belâgat, s. 231.

18 Akdemir, Belâgat, s. 231.

19 Söz konusu tartışmaların detaylı bir tahlili için bkz. Şensoy, Sedat, "Belâgat Geleneğinde Aklî Mecâz Tartışmaları", İslâm Araştırmaları Dergisi, sy. 8, 2002, s. 1-32.

20 Cürcânî, et-Ta'rîfât, s. 170.

21 Cürcânî, Delâilu'l-îcâz, s. 296.

22 Kazvînî, el-Izâh, s. 32.

YIL: 6 SAYI: 11 
Bu tür mecâza örnek olarak "ve yeryüzü ağırlıklarını çıkardığında"23 ayeti örnek verilebilir. Burada kudret sahibi olmayana bir güç isnad edilmektedir. Kudret sahibi olmayan bir faile bir fiil isnad etmek aklın hükümlerine aykırıdır. Dolayısıyla burada aklî bir mecâz söz konudur. ${ }^{24}$ Ayetin bu şekilde yorumlanması Cürcânî'ye göredir.

Lüğavî Mecâz: Kendisi için vaz’ olunmadı̆̆ı manada kullanılan lafızdır veya lafzın vaz' olunmadı̆̆ı manada kullanılmasıdır. Daha geniş bir ifadeyle herhangi bir alâkadan dolayı konulduğu mana dışında kullanılan ve aslî manasının kast edilmesine engel bir delil bulunan lafızdır. ${ }^{25} \mathrm{Me}-$ selâ, cesaretli bir kişiye aslan denilmesi bu tür mecâza örnek verilebilir. Lugâvî mecâz istiâre ve mecâz-1 mürsel şeklinde ikiye ayrılır.

İstiâre: Kendisindeki alâkanın daima müşâbehet olduğu lugavî mecâzdır. İstiâreye bir tarafı hazfedilmiş teşbih de diyebiliriz ${ }^{26}$. Meselâ, "Allah, iman edenlerin dostudur, onları karanlıklardan nura çıkarır"27 âyetinde zulümât ve nur kelimeleri hakikî mânâlarının dışında kullanılmışlardır. Zulümâttan kastedilen dalâlet, nurdan kastedilen ise hidâyet ve imandır. Âyet, Allah, onları karanlıklar gibi olan dalâletten, nur gibi olan hidayete çıkarır şeklinde anlaşılmalıdır. Burada teşbihin müşebbeh (benzetilen) kısmı hazfedilerek, bir mecaz çeşidi olan istiâre yapılmıştır. ${ }^{28}$

Mecâz-ı Mürsel: Mecâzda alâka müşâbehet dişında bir şey olursa, buna mecaz-1 mürsel denir. ${ }^{29} \mathrm{Bu}$ bahiste otuza yakın alâka sayılmıştır. Bunun da ayrıntısına girmeden en çok kullanılanları zikretmekle yetiniyoruz:

1. Sebebiyet: Sebebi söyleyip müsebbebi kastetmektir. Meselâ; Araplar, "hayvanlar yağmur otladı" derken, yağmur ile otları kastederler, zira yağmur otların sebebidir. ${ }^{30}$

2. Müsebbebiyet: Neticeyi söyleyip, bundan sebebi kastetmektir. Meselâ, tefsirciler, "Sizin için semâdan rızık indirir"31 âyetinde geçen r1-

23 Zilzâl, 99/2.

24 Cürcânî, Delâilu'l-îcâz, s. 296.

25 Cürcânî, et-Ta'rîfât, s. 170; Hâşimî, Cevâhiru'l-belâga, s. 251.

26 Hâşimî, Cevâhiru'l-belâga, s. 303.

27 Bakarâ, 2/257.

28 Tavîle, Abdulvehhâb Abdusselâm, Eseru l-luga fỉ ihtilâfi l-müctehidîn, Misır, ts., s. 152.

29 Hâşimî, Cevâhiru'l-belâga, s. 291.

30 Ali el-Cârim, Mustafa Emin, Belâgatu l-vâdıha, s. 109; Tavîle, Eseru'l-luga, s. 152.

31 Mü’mîn, 40/13. 
zıktan, onun sebebi olan yağmurun kastedildiğini belirtmişlerdir. ${ }^{32}$

3. Cüz'iyet: Parça söyleyip bütün kastedilir. Meselâ, "boynunu sal1vermek" ${ }^{\prime 3}$ ibaresinde boyundan kastedilen, insanın kendisidir. ${ }^{34}$

4. Külliyet: Bütün zikredilerek parça kastedilir. "Parmaklarını kulaklarına tıkadılar" ${ }^{35}$ ayetinde kastedilen parmakların hepsi değil, uçlarıdır. ${ }^{36}$

5. Mâziyet: Bir şeyin öncesini zikredip, bulunduğu hâli kastetmektir. Hz. Nuh'un (a.s.) duasında dediği gibi "yetimlere mallarını veriniz" ${ }^{37}$ ayetinde yetim, babası ölen küçük çocuk demektir. Âyette ise malların kendisine verilmesi emredilen kişi, artık rüşd çağına erip çocukluktan çıkmiştır. ${ }^{38}$

6. Müstakbeliyet: Bir şeyi sonradan alacağı durum ile zikretmektir. "Nûh: Ya Rabbî, dedi, yeryüzünde dolaşan bir tek kâfir bile birakma! Zira burakırsan onlar senin kullarını senin yolundan saptırırlar ve sadece kendileri gibi facir, kâfirden başka doğurmayacaklar". ${ }^{39}$ Esasen doğan yeni çocuk kâfir veya facir değildir. Âyette söz konusu olan, bunların ileride kâfir ve facir olacaklarıdır. ${ }^{40}$

\section{Belâgat İlminde Sarîh ve Kinâye Kavramları}

Belâgatın beyân ilmi çerçevesinde ele alınan diğer bir halkası da sarîh-kinâye kavramlarıdır. Klasik belagât eserleri kinâyenin gerek tanımı gerekse de kategorileri hakkında farklı sınıflandırmalarda bulunmuşlardır. Kinâyenin, "söz içinde geçen asıl anlamın yanında bir başka lazımî mananın anlatıldığı kelime ve terkip" olduğunu ifade ederek, kinâye kavramını "taşıdığı anlamın kastedilmesinin yanında lazımî anlamı istenen sözdür" şeklinde tanımlamışlardır. Cömert bir insana "eli açık" denilmesi kinâye-

32 Ali el-Cârim, Mustafa Emin, Belâgatu l-vâdıha, s. 109; Tavîle, Eseru l-luga, s. 152.

33 Beled, 90/13.

34 Bilgegil, M. Kaya, Edebiyat ve Bilgi Teorileri, İstanbul 1987, s. 169; Ali el-Cârim, Mustafa Emin, Belâgatu l-vâdıha,s. 109

35 Nûh, 71/7.

36 Bilgegil, Edebiyat, s. 171; Ali el-Cârim, Mustafa Emin, Belâgatu l-vâdıha, s. 109.

37 Nisâ, $4 / 2$.

38 Tavîle, Eseru'l-luga, s. 153; Ali el-Cârim, Mustafa Emin, Belâgatu l-vâdıha, s. 109.

39 Nûh, 71/26-27.

40 Tavîle, Eseru l-luga, s. 153; Ali el-Cârim, Mustafa Emin, Belâgatu l-vâdıha, s. 109.

YIL: 6 SAYI: 11 
ye örnektir. Ancak Arap dilinde cömert anlamında kullanılan "külü bol" ifadesi aynı zamanda külünün gerçekten bolluğunu da işaret edebilir. ${ }^{41}$ Kinâye bu yönüyle mecâzdan ayrılır. Zira mecâzda sadece mecâzî anlam kastedilir ve gerçek anlamın anlaşılmasına engel olan bir karine bulunmaS1 gerekir. ${ }^{42}$

Diğer bir tanım ise, "konuşanın dilde va'zedilen anlamı dışında redifi olan bir anlamı delil getirerek ifade etmek istediği anlama imâda bulunmasıdır” şeklinde Cürcânî (ö. 471) tarafından yapılmıştır. ${ }^{43}$

Klasik kaynaklar kinâye kavramını bu şekilde tanımlarken, modern dilciler tarafından en çok kabul edilen kinâye tanımı "gerçek manayı düşünmeye engel olacak bir karîne bulunmamak şartıyla bir sözü gerçek manasına da gelebilmek üzere onun dişında kullanma sanatıdır"44 şeklindedir. Bugün dilciler tarafindan kabul edilen temel tanım bu olmuş olsa da, söz konusu tanımın yanıltıcı olduğunu ifade eden araştırmacılar da bulunmaktadır. ${ }^{45}$ Kinâye için yapılan tanımlardan biri de "bir sözün hem gerçek hem de mecâz anlamını kastederek kullanmadır" şeklindedir. ${ }^{46}$ Burada kinâyenin telvih kavramıyla karıştırıldığı ifade edilmektedir. Bu tanımda kinâye, mecâz ve hakîkî kavramlarla irtibatlandırılmış ancak gerçek anlamı olan "örtülü anlatım” özelliği yansıtılmamıştır. ${ }^{47}$

Gerek klasik gerek modern dil kaynakları bağlamında kinâyenin neliği hususunun tartışmalı olduğu görülmektedir. Söz konusu bu durum dile ve lafza dayalı anlama faaliyetleri gerçekleştiren fikı usûlü ilmine de yansımaktadır. Bu bağlamda fikhî hükümlerin de farklılaşması gündeme gelmektedir.

41 Örnek olarak bkz. Kazvînî, el-Îzâh, s. 243; Ali el-Cârim, Mustafa Emin, Belâgatu l-vâzıha, s. 125.

42 Durmuş, İsmail, "Kinâye", DİA, 2002, XXVI, 34.

43 Cürcânî, Delâilu'l-îcâz, s. 66.

44 Bilgegil, Edebiyat, s. 174; Bolelli, Nusrettin, Belâgat: Arap Edebiyatı Bilgi ve Teorileri, İstanbul, 1993, s. 123.

45 Söz konusu ifadeler ve Belâgat ilminde kinâye kavramının daha geniş tanımı ve tahlili için bkz. Coşkun, Mendres, "Kinâyenin Belâgât Kitaplarındaki Seyri ve Onu Yeniden Anlama ve Sunma Denemesi, BÍLIG, 2008, sy. 44, s. 63-88, 68.

46 Soysal, M. Orhan, Edebi Sanatlar ve Tanınmasi, Ankara, 1992, s. 58.

47 Coşkun, a. g. m., s. 69. Yazar burada bu iki kavramın eskiden beri karıştırıldığını ifade eden araştırmacıların da olduğunu ifade etmektedir. 


\section{A. Kinayenin Çeşitleri}

Kinâye kendisine işaret edilen ve söz içinde geçmeyen unsur bakımından, sıfat, mevsuf, nisbe kinâyeleri şeklinde sinıflanırken, ortaya konulurken kullanılan araçlar bakımından telvih, remiz, imâ ve işaret, ta'rîz şeklinde dört kısma ayrılmıştır. ${ }^{48}$ Kinâye özellikle ta'rîz ile karıştırıldığgndan bu son ayrımı kısaca ifade etmek istiyoruz.

1. Telvih: Eğer kinâyede mânâlar arasındaki vasıtalar çok olursa buna telvih denir. ${ }^{49}$ Meselâ; Arapça da adamın külünün çok olması, cömertliğinden kinayedir. Çünkü kül, çok odun yakmaya; bu, çok yemek pişirildiğine; bu da, çok misafiri olup onları cömertçe ağırladığına delalet eder. ${ }^{50}$

2. Remiz: Eğer uzak ve yakın mânâlar arasındaki vasıtalar az ve gizli olursa, kinâye remiz adını alır. ${ }^{51}$ Meselâ, Arapça' da filanca istirahat edenlerdendir, denildiği zaman bundan, o insanın tembel ve aptal olduğu anlaş1lır.

3. İma ve İşaret: Bunda da vasıta az olup, ima ve işaret vardır. Meselâ, fazilet, falanın gittiği yöne doğru gitti, ifadesinde faziletin o şahsa nispet edildiği anlaşılır.

4. Ta'riz: Kelâmın mutlak bırakılıp, ne kastedildiğinin siyâkından anlaşıldığı sözlerdir. Meselâ, insanlara zarar veren kimseye insanların en hayırlısı onlara faydalı olandır" denilmesi ta'rîze örnek verilebilir. ${ }^{52}$

\section{Fıkıh İlminde Hakîkât ve Mecâz Kavramları}

Arap dilinde mecâz kavramı, beyân ilmi çerçevesinde ele alınırken fikıh bilginleri tarafından lafız bahislerinde işlenmişstir. Dolayısıyla her iki ilim dalı mecâz kavramını ayrı bir sistematik dahilinde işlemiştir. Arap

48 Kazvînî, el-Izâh, s. 248. Kazvînî eserinde Sekkâkî’nin kinâyeyi bu kısımlara ayırdığını ifade etmektedir.

49 Kazvînî, el-Izâh, s. 248.

50 Tavîle, Eseru'l-luga, s. 164.

51 Kazvînî, el-Izâh, s. 248.

52 Kazvînî, el-Izâh, s. 248.

YIL: 6 SAYI: 11 
dilindeki beyân, bir anlamı değişik yollarla ifade etmeyi öğreten ilim dalı olarak işlev görürken fikı ilminde beyân, manadaki kapalılı̆̆ı gidermeye yarayan bir terim olarak kullanılmaktadır. ${ }^{53}$

Yukarıda ifade ettiğimiz gibi mecâz kavramı edebi sanatlardan olması hasebiyle esasen belâgat ilminin konusunu oluşturmaktadır. Ancak lafzı anlamaya çalışan bütün ilimler mecâz kavramını konu almışlardır. Söz konusu anlama faaliyetinin en yoğun olduğu ilim dallarından biri de fikıh usûlüdür. Hatta İslam geleneği içinde kapsamlı bir anlama yöntemi geliştiren tek disiplinin fikıh usûlü olduğu belirtilmektedir. ${ }^{54} \mathrm{Bu}$ ilmin anlama yöntemi daha ziyade lafız-mana ilişkisine dayanır. Fıkıh usûlünde lafız ve mana ile ilgili yapılan tasniflerden bu durumu çok rahat görebiliriz. Arap dili belâgatında "beyân teorisi" çerçevesinde ele alınan mecâz kavramı, fıkıh usulünde "delâlet teorisi”" kapsamında işlenmiştir.

F1kıh usûlünde bir kavramın hakîkât ya da mecâz olarak kabul edilip kullanılabilmesi için, dilbilimcilerin söz konusu o kelime hakkında, “o'nun hakikat manası budur, mecazi manası ise şudur” diye açıklamada bulunmaları ve hakîkât ya da mecâz manada kullanıldığına dair delil ileri sürmeleri esastır. ${ }^{55}$ Her iki terimin de tanımını yaparken dilbilimcilerin, kelimelerden birinin hiç değişikliğe tabi tutulmadan ilk manadaki gibi, diğer kelimenin ise ilk konulduğu mananın dışında kullanıldığına dair beyanda bulunmaları, söz konusu terimler için tanımlayıcı mahiyette kabul edilir. $^{56}$

Mecâz ve hakîkatin fikıhtaki en büyük yansıması ve etkisi müçtehidlerin hüküm istinbâtında ortaya çıkmaktadır. Zira metinde geçen lafzın mecâzî ya da hakîkî manada kullanılıp kullanılmadı̆̆ı hususu fukahâ arasında tartışılmıştır. Bu bağlamda farklı mezhepler aynı dini metinler üzerinde farklı hükümlere varmışlardır. Dolayısıyla fukahânın ihtilaflarının

53 Dönmez, İbrahim Kafi, "Beyân”, DİA, 1992, VI, 25.

54 Görmez, Mehmet, Sünnet ve Hadisin Anlaşılmasinda Yöntem ve Metedoloji Sorunu, Ankara, 2000, s. 21.

55 Cessâs, Ahmet b. Ali er-Râzî, el-Fusûl fi'l-Usûl, Kuveyt, 1985, I, 367; Serahsî, Ebû Bekr Muhammed b. Ahmed, Usûlu's-Serahsî, Beyrut, 1973, I, 177-78; Gazâlî, Muhammed b. Muhammed, el-Mustasfâ min İlmi'l Usûl, Misır, 1322, I, 343.

56 Şevkânî, Muhammed b. Ali, İrşâdu'l-Fuhûl, (thk.Ebi'l-Hafs Sami b.El-Arabi), Riyâd, 2000, I, 141. 
temelinde mecâz ve hakîkât kavramlarının da bulunduğunu ifade edebiliriz. Bu durum söz konusu kavramların belâgat ilminde olduğu kadar fikıh ilminde de ihtilaflara sebep olduklarını göstermektedir.

Hakîkât terim olarak, lafzın konulduğu ve tahsis edildiği manaya delâletidir. Yani bir kelimenin ilk ve aslî manasında kullanılmasıdır, asıl olarak hangi anlam için konulmuş ise o anlamı ifade etmek için kullanılan lafızdır. ${ }^{57}$ Günlük yaşantımızda etrafımızdaki canlı veya cansız varlıklara verilen isimleri çoğunlukla hakîkât anlamında kullanırız. Mesela; "ay” kelimesi ile geceleyin dünyamızı aydınlatan gezegenin, "kar” kelimesi ile kış mevsiminde gökten yağan beyaz maddenin kastedilmesi böyledir. Yine, yediğimiz, içtiğimiz, giydiğimiz ve günlük hayatta kullandığımız şeylere verdiğimiz isimler hakîkî manada kullanılan lafızlara örnektir. Özetle Şarî'in, dil bilimcilerin veya dili konuşanların herhangi bir manada kullandıkları lafizlar karinesiz veya vasıtasız anlaşılıyorsa, o lafızlar hakiki manada kullanılmış kabul edilir.

Usulcüler hakîkâti kullanımı bakımından üç kısma ayırmışlardır:

Müteazzir/Aklen İmkansız hakîkât: Kendisine ancak külfet ve meşakkat sonucu ulaşılan hakikattir. Mesela bir kişi şu ağaçtan yemeyeceğim diye yemin etse ve bizatihi ağaçtan yese, burada hakîkât manasının anlaşılmasının aklen imkansızlığı söz konusudur. ${ }^{58}$ Zira kullanılan ifade burada ağacın meyvesini kastetmektedir. Dolayısıyla ağacın meyvesinden değil de kendisinden yemesiyle, yemini bozulmuş olmaz.

Mehcûr/Terk edilmiş Hakîkât: Ulaşılması kolay olsa da insanların kullanımı terk ettiği hakîkâttir. Mesela filanın evine ayak basmayacağım diye yemin edilse, sonra da mücerred olarak eve basmış olsa yemininden dönmüş olmaz. Zira mücerreden eve ayak basma âdeten kullanılmaz. Yemininden dönmüş olması için evin içine girmesi gerekir. ${ }^{59}$

Müsta'mel Hakîkât: Mehcur olan hakikatin aksine insanların kullanımı terk etmediği hakîkâttir. Meselâ birisi şu koyundan yemeyeceğim diye yemin etse, bu söz koyunun sütü ve yünü için değil eti için anlaşılır. Zirâ kullanılan (müsta'mel olunan) hakîkât mana koyunun etidir. ${ }^{60}$ Dola-

57 Cessâs, el-Fusûl, I, 359; Serahsî, Usûlu's-Serahsî, I, 170.

58 Serâhsî, Usûlü 's-Serâhsî, I, 172.

59 Serâhsî, Usûlü 's-Serâhsî, I, 172; Şâşî, Nizâmuddîn, Usûlü 'ş-şâş̧î, Beyrût, 2000, s. 47.

60 Şâşî, Usûlü'ş-şâş̧î, s. 49-59.

YIL: 6 SAYI: 11 
yısıyla kişi koyunun etinden yerse yemini bozulmuş olur.

Terim olarak mecâz, lafzın asıl manasından alınıp, aralarında ilginin ve benzerliğin bulunmasından dolayı başka bir manaya nakledilmesidir. Bir başka ifadeyle, asıl mananın anlaşılmasına yönelik bir engelden dolayı lafzın başka bir anlamda kullanılmasıdır. Meselâ kurnaz olan bir insana tilki ifadesinin kullanımı, kavramın mecâzî anlamını ifade etmektedir. ${ }^{61}$ $\mathrm{Bu}$ yönüyle mecâz, bir alâka münasebetiyle hakiki manasının dışında bir anlamda kullanılan lafız şeklinde tanımlanır. ${ }^{62}$ Özellikle fukahâ metoduyla telif edilmiş usul kitaplarında lafzın vazolunduğu manada kullanılıp kullanılmadığına göre yapılan ayrım içerisinde incelenen mecâz, lafzın vaz'edildiği manada kullanılması anlamına gelen hakîkâtin zıddı olduğu gibi yine aynı ayrım içinde yer alan, fakat başka bir açıdan yapılan sarîh-kinâye nitelemesindeki kinâyeden de farklı değerlendirilir. ${ }^{63}$ F1kıh ilminde hakîkât ve mecâz kavramlarına dair lafzın manaya ya da hükme delâleti hususu çerçevesinde bazı tartışmalı konular mevcuttur.

\section{A. Hakîkât ve Mecâzın Birleştirilmesi}

Ulemâ, içinde hakîkî manayı da barındıran bir lafzın mecâzî manada kullanılmasının cevazı hususunda ittifak etmişlerdir. ${ }^{64}$ Ancak bir lafzın aynı anda hem hakîkât hem de mecâz anlamda kullanılması hususunda ihtilaf vardır. Hanefî mezhebinin tamamı ${ }^{65}$, Mutezile ve Şâfiilerin bir kısmı$\mathrm{na}^{66}$ göre bu konuya müspet cevap verilemez. Yani bir lafız aynı anda hem mecâz hem hakikat anlamını barındıramaz. Kerhî (ö. 340) "bir halde hem mecâz hem de hakîkî manayı kullanmanın caiz olmayacağını" zira bu, bir halde hakîkî lafzın mecâzen olmasını gerektirir ki, bu da muhaldir". ${ }^{67}$

61 Hakikat ve Mecaz terimlerinin fikıh ilmindeki terminolojik anlamları için bkz.Cessâs, elFusûl, I, 359; Serahsî, Usûlu’s-Serahsî, I, 170; Gazâlî, el-Mustasfâ, Misır, I, 341; Râzî, Fahreddîn b. Muhammed, el-Mahsûl fi i'lmi'l-Usuli'l-fikh, Beyrut 1992, I, 285; Şevkânî, İrşâdu'lFuhûl, I, 135.

62 Nesefî, Ebu'l-Berekât, Keşfu'l-esrâr şerhu'l-musannifi ale'l-menâr, İstanbul, 1986, I, 155; Molla Cîven, Nûru'l-envâr, I, 155.

63 Koca, Ferhat, "Mecaz”, Di், 2002, XXVI, 220.

64 Söz konusu bu düşünce umûmu'l-mecâz ifadesiyle literatürde ele alınmıştır. Râzî, el-Mahsûl, I, 343; Tavîle, Eseru'l-luga, s. 172.

65 Cessâs, el-Fusûl, I, 369; Serahsî, Usûlü 's-Serâhsî, I, 173; Şevkânî, İrşâdul'-Fusûl, I, 196.

66 Râzî, el-Mahsûl, I, 344.

67 Cessâs, el-Fusûl, I, 46. 
Hakîkât mecâzın zıddıdır. Dolayısıyla bir lafız bir defada iki zıt anlamı ifade edemez. Diğer yandan bu görüşü savunanlar, beyân ulemasının, bir lafzın mecâzi anlamı ifade etmesi için hakîkî manaya engel olan bir delilin bulunması gerektiği, şartını ileri sürdüklerine dikkati çekmektedirler. Ayrıca dil ehlinin bir lafzı hakîkî ve mecâzî manada birlikte kullanmadıklarına vurgu yapmaktadırlar. ${ }^{68}$

İmâm Şâfi'î (ö. 204) ve Şâfi'îler arasında muhtar olan görüşe göre ise, bir kelimenin hem hakîkât hem de mecâz manada kullanılması aklen mümkündür ve vuku bulmuştur. Söz konusu kullanımın Kur'an'da da örneğinin bulunduğunu ifade eden bu görüş sahipleri, nikâhın hem evlilik hem de cinsel birliktelik manasında kullanıldığını delil olarak getirmişlerdir. ${ }^{69}$

\section{B. Hakikât ve Mecâzın Teâruzu}

Bazen bir metinde bir lafiz hem hakîkât hem de mecâz manaya hamledilecek şekilde kullanılmış olabilir. Bu durumda fukahâ arasında hangi lafza göre hüküm beyân edileceği hususunda farklı yorumlamalar vardır. Bunları aşağıdaki şekilde ifade edebiliriz:

1. "Kelamda aslolan hakîkî manasıdır". ${ }^{70}$ Bu kaide şu sonuçları ortaya çıkarır: Söyleyenin niyetine bakılmaksızın ister umum ister husus, ister emir isterse de nehiy olsun lafzın konulduğu mana mutlak olarak sabit olur. Lafız, şer'i mecâz ya da şer'i hakikat arasında olursa, hakikat manası tercih edilir. Yine aynı şekilde lafız, örfî mecâz ve örfî hakîkât arasında olursa hakîkât manasına hamledilir. ${ }^{71}$

2. "Manayı hakiki müteazzir oldukta mecaza gidilir". ${ }^{72}$ Zira mecâz ittifakla hakîkâtin halefidir. Mesela birisi evini, evladına ya da başkasının çocuğuna vakfetse bunun içine o çocuğun çocuğu dahil olmaz. Arap dilindeki "veled" lafzının hakîkî manası kişinin kendi sülbünden olan çocuğudur. Ancak çocuğu yoksa o takdirde kavramın mecâzi anlamı devreye

68 Tavîle, Eseru'l-luga, s. 172.

69 Âmidî, Alî b. Muhammed, el-İhkâm fì usûli 'l-ahkâm, (tah. Abdürrezzâk Afîfî), Riyâd, 2003, I, 37.

70 Mecelle-i Ahkâm-ı Adliye, Hikmet Yayınları, İstanbul, 1985, mad., 12.

71 Serâhsî, Usûlü's-Serâhsî, 172; Tavîle, Eseru'l-luga, s. 169.

72 Mecelle, mad., 61.

YIL: 6 SAYI: 11 
girebilir. ${ }^{73} \mathrm{Bu}$ kaidenin ortaya çıkardığı sonuçları şöyle ifade edebiliriz: Eğer mecâz anlam kastediliyorsa, umum, husus olsun ya da hakikî manası içine dahil olsun, yine de mecâzî anlam sabit olur.

Hakikatin mecâz üzerine tercih edilmesi ancak dişarıdan bir karine olmamasıyla mümkündür. Ancak hakikatin asıl, mecâzın ârız olması mecâzda karineye ihtiyaç olması sonucunu doğurur.

3. Hakikât ve mecâzın aklen mümkün olmadığı yerde kelâm da imkansız hale gelir. Mesela bir kişi kendinden yaşça büyük, yaşlı ve nesebi bilinen eşine "bu benim kızımdır" dese, lafız ne hakikât ne de mecâz olan anlamina hamledilemez.

4. Eğer hakikât anlamının kullanımı yaygın ve mecâzî anlama sebep olacak bir karîne de yoksa lafzın hakîkât anlamının tercih edilmesi daha uygundur.

5. Lafzın hakikî ve mecâzî anlamının yaygın kullanımı aynı oranda ise, o zaman kelamda aslolan hakikî manasıdır ilkesi gereği yine hakîkât manasi tercih edilir.

6. Lafzın mecâz anlamı kullanımda ve hakîkât anlamı terk edilmiş ise, mecâz tercih edilir. Ancak mecâz anlamı çok kullanılsa fakat hakîkât anlamı da şer'an veya âdeten terk edilmemişse bu durumda farklı görüşler ileri sürülmüştür. Ebû Hanîfe'nin de içinde bulunduğu bir gruba göre, bu durumda asıl olduğundan hakîkât manası tercih edilir. Ancak diğer bazı görüsslere göre, râcih olduğundan dolayı mecâz anlam tercih edilmelidir. ${ }^{74}$

Hakîkât ve mecâz hususunda dikkate değer bir durum daha söz konusudur. Her iki kavram için de sarîh ve kinâye kategorileri mevcuttur. Mecâz, anlaşılmasına kadar kinâye hükmündedir. Ancak anlaşıldıktan sonra sarîh hükmünde kabul edilir. ${ }^{75}$

\section{Fıkıh İlminde Sarîh ve Kinâye Kavramları}

Fukahâ metoduyla eser veren usulcüler, fikıhta hüküm çıkarma konusunu ele alırken lafız-mana ilişkisini lafzın vazolunduğu mana, lafzın vazolunduğu manada kullanılması, kullanıldığı manaya delaletinin açıklık ve kapalılığ ile kullanıldığ

73 Serahsî, Usûlü 's-Serâhsî, I, 173; Şâşî, Usûlü 'ş-Şâ̧̧̧î, s. 49-59.

74 Şâşî, Usûlü'ş-şâş̧î, s. 49-54.

75 Şâşî, Usûlü'ş-şâş̧î, s. 65-67. 


\section{$272 \cdot$ YALOVA SOSYAL BILIMLER DERGISI}

başlık altında incelemişlerdir. ${ }^{76}$ Lafzın vazedildiği manada kullanılıp kullanılmadığını gösteren birinci ayırım yukarıda da ele almış olduğumuz hakîkât-mecâz kavramlarıdır. Sarîh ve kinâye de, bu açıdan yapılmış bir başka ayırım olmuştur. Kinâye kavramını Serâhsî (ö. 490), "bir delil vasttasıyla ortaya çıkıncaya kadar kendisinden murat edilen maksat gizli olan ve kendi anlamında tereddüt bulunan her şey"77 şeklinde tanımlanmıştır. Bunun zıddı olan sarîh ise "ister hakîkât ister mecâz anlamında kullanılsın kendisiyle kastedilen mana açıkça anlaşılan lafı" 78 şeklinde beyan edilmiştir. Böyle olunca sarih-kinaye, lafzın, söyleyenin kastı bakımından vâz’i manasında kullanılıp kullanılmadığını, kapalılık taşıyıp taşımadığını belirlemeye yarayan bir rol üstlenir. Bunun için de hakikat ve mecazdan her birinin bu ikinci açıdan kendi içinde sarih ve kinayeye ayrılması söz konusudur. $^{79}$

Kinâyenin hem hakîkât hem mecâzla yakın ilgisi vardır. Bunun için kinâyenin hakîkâte mi mecâza mı dahil olduğu usulcüleri fazlasıyla meşgul eden bir konu olmuştur. Ancak kinâyeye hem hakîkî hem de mecâzi anlamda kullanılan kelimeler girebilir. Terkedilmiş hakîkî manalar, herkes tarafından bilinmeyen ve meşhur olmayan mecâzlar da kinâyeden sayılır. Mesela bir erkek karısına «ailene dön" dediği zaman bununla sadece onun babasının evine dönmesini kastetmesi hakiki, "dön" sözünü "boşamak" anlamında söylemesi ise mecâzî bir kullanımdır. Bu durumda adı geçen kocanın bu kelime ile boşamayı kastedip etmediği veya kaç talakı kastettiği hususunda kapalılık bulunmaktadır. Dolayısıyla bu mecaz kinayeye dönüşür ve ondaki kapalılık ancak kocanın kendi kastını açıklaması veya başka bir karinenin bulunmasıyla giderilir. Bu sebeple hafî, müşkîl, mücmel gibi kapalı lafızlar, yaygın olmayan mecâzlar, hakîkî anlamından uzak bir şekilde çokça kullanılan mecazlar ve manalarından biriyle meşhur olan müşterek-sarîh kelimeler de kinâyenin kapsamı içerisine girer. ${ }^{80}$ Bu durumda kinâyenin mecâzdan daha kapsamlı bir kavram olduğu ayrıca

76 Fukaha metoduna göre bu manada ilk tasnif Debûsî'nin Takvîmu'l-edille'sinde geçmektedir. Bkz. Debûsî, Ömer b. Îsâ, Takvîmu'l-edille fì usûli'l-fikh, (tah. Halîl Muhyiddîn Meys), Beyrût, 2001, s. 94-159.

77 Serahsî, Usûlü's-Serâhsî, I, 187-188.

78 Serahsî, Usûlü 's-Serâhsî, I, 187.

79 Koca, "Kinaye", s. 36.

80 İbnü'l-Hümâm, et-Tahrîr, ( İbn Emîru Hâc, et-Takrîr ve’t-tahbîr içinde), Bulak 1316, II, 38-39.

YIL: 6 SAYI: 11 
fakihlerin de kinâyenin kapsamını dilcilere göre daha geniş tuttukları görülür. ${ }^{81}$

Bir kısım, kinâyenin mutlak anlamda hakîkât olduğunu ifade etmişlerdir. Mecâz kavramında ise, hakîkî mananın kastedildiğine bir engel bulunması gereklidir. Mesela "hamamda aslan var" ifadesinden gerçekten bir aslanın kastedildiği düşünülmez. ${ }^{82}$ Kinâyede hakîkât manasının da kastedilme ihtimalinden dolayı onun hakîkât kabilinden sayılması gerektiği çoğunluğun görüşü olsa da, kinâyenin mecâz, ne hakîkât ne mecâz, kısmen hakîkât, kısmen mecâz olduğunu söyleyenler de olmuştur. ${ }^{83}$

\section{Mecâz ve Kinâye Kavramlarının Fıkhî Hükümlere Etkisi}

Mecâz ve kinâye kavramları, mezhep ekollerinin farklı hükme varmalarında önemli dayanaklardan biridir. Fukahâ, dilden kaynaklanan farklı anlayışlarından dolayı ihtilaflı olan hükümlere varmışlardır. Söz konusu dile dayalı problemli konulardan biri de hiç şüphesiz dini metinlerde geçen lafızların hakîkî, mecâzî ya da kinâyî anlamda kullanılıp kullanılmadığının tespit edilmesidir.

F1kıh ilminin amaçlarından biri de, ana kaynağı olan Kitâb'1 doğru anlamaya çalışarak Şâri’nin maksadını doğru bir şekilde ortaya koyabilmektir. Bu manada fukahâ metinlerde geçen lafizlardan Arap dilinin kuralları çerçevesinde hüküm çıkarmak için çaba harcamıştır. Biz bu başlık altında Kitâb'da geçen ve farklı anlam çerçevelerine sahip olan mecâz ve kinâye lafızlarının fukâhânın farklı fikhî hükme varmalarına nasıl etki ettiğini örnekler üzerinden vermeye çalışacağız.

Bu konuda gerek dilciler gerekse de fukahâ arasında farklı anlaşılan âyetlerden en dikkat çekeni, Mâide suresinde abdestle ilgili hüküm ifade eden ayettir. Söz konusu âyet "Hasta, yahut yolculuk halinde bulunursaniz, yahut biriniz tuvaletten gelirse, yahut da kadınlara dokunmuşsanız (cinsî birleşme yapmışsanız) ve bu hallerde su bulamamışsanız temiz toprakla teyemmüm edin de yüzünüzü ve (dirseklere kadar) ellerinizi onunla

81 Koca, "Kinâye", s. 37.

82 Sekkâkî, Ebû Yâkub, Miftâhu'l-Ulûm, Beyrût, 2000, s. 513.

83 Sekkâkî, Miftâh, s. 523. 
meshedin" 84 şeklindedir.

Ayette geçen "el-lems" ibaresi Arap dilinde hem hakîkî hem de mecâzî anlamı ifade eden müşterek bir lafizdır. Çünkü Arapça〉da «el-lems», bazen el ile dokunmayı ifade eder, bazen de cimâdan kinaye olarak kullan1lur. ${ }^{85}$

Dildeki bu farklılıktan dolayı ulemâ söz konusu âyetin manasında ihtilâf etmişlerdir. İbn Mesud, İbn Ömer, Nehaî (ö. 96), Şa〉bî (ö. 143), Atâ (ö. 117), İbn Sîrîn (ö. 110) buradaki "lems"in hakikî mânâda kullanıldığgn1, yani el ile dokunma mânâsına geldiğini ifade ederler. Hazreti Ali, İbn Abbas, Hasan (ö. 110), Katade (ö. 118) ve Mücahid (ö. 104) ise, “el-lems"in cinsî münasebetten kinaye olduğunu söylerler. ${ }^{86}$

Hanefîler ve rivayet edilen bir kavline göre İmam Ahmed b. Hanbel (ö. 241) "dokunma" lafzının cinsî münasebetten kinaye olduğunu dolayısıyla da abdestin mücerred dokunmayla bozulmayacağı sonucuna ulaşmışlardir. ${ }^{87}$ Malikî fukahâya göre ise, ayetteki "mülâmese" hakikî mânâsındadır, kadınla erkeğin birbirine şehvetle dokunmaları durumunda abdestlerinin bozulacağına hükmetmişlerdir. ${ }^{88}$

Şâfîi mezhebinde meşhur olan görüşe göre dokunmanın şehvetle olup olmamasına itibar edilmez. Burada, lafzın hakîkî manasından dolayı her türlü dokunma abdesti bozar. ${ }^{89} \mathrm{Bu}$ misalde görüldüğü üzere mecâz-hakîkât kavramlarına yüklenen mana, fikhî bir ihtilâfa sebebiyet vermiştir. Buradan hareketle, Hanefî̀ ve Şâfiî çevrelerce kadına dokunmayla abdestin bozulup bozulmayacağı hususunda iki farklı uygulama ortaya çıkmıştır.

Başka bir mesele üzerinde konuya değinecek olursak, meselâ, "Üzerine Allah'ın adı anılmadan kesilen hayvanların etini yemeyin"90 âyetinden yola çıkarak Hanefîler, tesmiyenin hayvanın boğazlanması esnasında 84 Mâide, 5/6.

85 Tavîle, Eseru'l-Luga, s. 193.

86 Serahsî, a.g.e I, 173; Nesefî, Keşfu'l-esrâr, I, 163; Molla Cîven, Nûru'l-envâr, I, 163.

87 Serahsî, Usûlü 's-Serâhsî, I, 178; Cessâs, el-Fusûl, I, 46; İbn Kudâme, Ebû Muhammed Muvaffakuddin Abdullah b. Ahmed b. Muhammed, el-Muğnî, (tah. Abdullah b. Abdulmuhsin et-Türkî, Abdullfettah Muhammed el-Hulv), Kâhire, 1982, I, 256.

88 İbn Cellâb, Hüseyn b. Hasan, et-Tefrî̀', (tah. Hüseyn b. Sâlim ed-Dehmânî), Beyrût, 1987, I, 213.

89 Nevevî, Kitâbu'l-Mecmû' şerhu'l-Mühezzeb li'ş-Şirâzîl, (tah. Muhammed Necîb el-Mutî̀̂̂), Cidde, ts., II, 29.

90 Nisâ, $4 / 4$.

YIL: 6 SAYI: 11 
olduğu görüşündedirler. Dolayısıyla, hayvan kesilirken Allah'ın isminin zikredilmesi gerekir. Besmelenin unutulması halinde kesilen hayvanın eti helâl olur, kasten terk edilirse helâl olmaz. Şafiîlere göre ise "kesim anında tesmiye" mecâzdır. Bundan kastedilen mana, hayvan kesmenin tesmiyeye sebep olmasıdır. Mecâzen sebep müsebbip gibi sunulmuştur. Bunun sonucunda tesmiye kasten terk edilse dahi hayvanın eti helâl olur. ${ }^{91}$

Yine "hamr"ın haramlığını ifade eden âyette, bu lafzın hakîkî mi mecâz mı olduğu hususunda fukahâ farklı hükme varmıştır. Hanefî̀ hukukçulara göre, hamr Arap dilinde; "kaynatılmadan, çiğ olarak kendi kendine kabaran, fokurdayıp köpük atan yaş üzüm suyundan elde edilen içki”ye verilen addır. Diğer alkollü içkilerin haramlığı kıyas yoluyla sâbit olduğundan bunlar için hamr ifadesi mecâzi olarak kullanılmıştır. Bu ayırım sonucunda İmam Muhammed dişındaki Hanefîlerle Nehaî, Sevrî, İbn Ebî Leylâ, Şüreyk ve İbn Şübrüme gibi hukukçular, naslarda zikredilen ve yalnızca çiğ üzüm suyundan yapıldığını ileri sürdükleri hamr'ın azı ve çoğunun haram olduğunu belirtmişler, diğer alkollü içkilerin sarhoş etmeyecek miktarda içilmesinin haram olmayacağını ileri sürmüşlerdir. İslâm hukukçularının büyük çoğunluğu, böyle bir ayırıma gitmeden az olsun çok olsun alkollü olan bütün içkilerin haram olduğunu belirtmişlerdir. $\mathrm{Bu}$ âlimlere göre, hamr, sadece üzüm suyundan elde edilen alkollü içecek değildir. Zira, bir şeyin her hangi bir adla anılması, onun dışındakilere o ismin verilemeyeceği anlamına gelmez. Araplar hamr denildiğinde bütün sarhoş edici içecekleri anlamışlardır. Dolayısıyla burada bu lafzın Araplar tarafından anlaşılan hakîkî anlamına itibar edilmelidir. ${ }^{92}$

Hz. Peygamber (s. a. v.)'in "Velisiz nikah olmaz"93 hadisi de fukahâ tarafından hakîkât ve mecâz kavramlarına bağlı olarak farklı yorumlanmıştır. Hadis, esasen velisiz nikahı reddetmektedir. Bu hadis, hakîkât ve mecâz olmak üzere iki manayı ihtivâ etmektedir. Söz konusu ifade hakîkî anlamı dikkate alınırsa nikahın sıhhati şeklinde anlaşılabilir. Ancak nikâ91 Mut'inî, Abdulazim İbrahim, el-Mecaz Fi'l-Luğa ve'l-Kur'âni'l-Kerim, Kâhire, ts. , I, 600-601.

92 Serahsî, Usûlü's-Serâhsî, I, 173; Şevkâni, Muhammed b. Ali, Neylu'l-Evtâr şerhu Munteka'l-ahbâr, Beyrût, 1973, VII, 157; İbn Rüşd, el-Hafid Ebu'l-Velid Muhammed b. Ahmed, Bidâyetu'l-muctehid ve nihâyetu'l-muktesıd, İstanbul, 1985, I, 382-383; Şirazî, Ebû İshak İbrahim b. Ali b. Yusuf el-Firuzabâdî, el-Mühezzeb fí fikhi'l-İmâmi'ş-Şâfíi, (tah. Muhammed Zuhaylî), Beyrût, 1996, V, 454.

93 Buhârî, "Nikâh", 37. 


\section{$276 \cdot$ YALOVA SOSYAL BILIMLER DERGISI}

hın kemâli manasında anlaşılırsa mecâzî anlamı ifade etmiş olur. Dolayısıyla fukaha velâyetin, nikâhın sıhhat şartlarından olup olmadığı hususunda ihtilafa düşmüşlerdir.

Ebû Hanîfe (ö. 150), Züfer, Şâ’bî ve Zührî söz konusu bu hadisi "kâmil bir nikah olmaz" şeklinde anlayarak hadisin mecâzî manasını tercih etmişlerdir. Hanefî ekol burada hakîkî mananın kastedilmiş olamayacağına "Eğer o kadınlar, (kendiliklerinden) çıkıp giderlerse, kendileri hakkında yaptıkları meşru şeylerden size bir günah yoktur"94 ayetini delil getirmişlerdir. Ve dolayısıyla kadınların kendileri hakkındaki tasarruflarının caiz olacağına hükmetmişlerdir. ${ }^{95}$

Şâfîler ise, söz konusu hadisi hakîkât manasına hamlederek, veli olmadan yapılan nikah akdinin caiz olmayacağına hükmetmişlerdir. Kadının kendisi velisinin iznini almış olsa bile nikah yapamaz. "Onların (eski) kocalarıyla evlenmelerine engel olmayın"96 ayetinde geçen "yenkihne" ifadesinin velilere "onları nikahlayın" şeklinde bir hitap olduğunu gerekçe göstermişlerdir. ${ }^{97}$

Hz. Peygamber (s. a. v.)' in 'taraflar birbirlerinden ayrılmadıkça muhayyerdirler" $" 98$ ifadesi de, hem hakîkât hem mecâz anlamıyla anlaşılabileceğinden fukahânın farklı hüküm vermesine sebep olmuştur. Hadiste ifade edilen mesele, fikıh literatüründe meclis muhayyerliği olarak bilinen durumdur. Meclis muhayyerliği, "îcab ve kabul yapıldığ ve akit tamam olduğu halde akdi yapanlar meclisi terk edip bedenen birbirinden ayrılmadıkları sürece îcab veya kabulden rücû etme imkânına sahip bulunmaları" ${ }^{\prime 99}$ olarak tanımlanmıştır. İmam Şafiî, Ahmet b. Hanbel ve Zâhiriler hadisi lâfzî yoruma tabi tutmuşlar ve hakîkî anlamını kabul ederek tarafların akit meclisinden bedenen-cismen ayrılma sonucunu çıkarmışlardır. Şâfî̀ ve Hanbelîlere göre, akit meclisi kabul beyanından sonra da devam

\footnotetext{
94 Bakarâ, 2/240.

95 Tahâvî, Ebû Cafer, Şerhu Me âni'l-Âsâr, (tah. İbrahim Şemsuddîn), Dâru'l-Kütübi'l-İlmiyye, I-IV, Beyrut, 2001, II, 364,365.

96 Bakarâ, $2 / 232$.

97 Mâverdî, Ebu'l-Hasen Ali b. Muhammed, el-Hâvî fî fikhi'ş-Şâfî, Dâru'l-Kütübi'l-İlmiyye, (tah. Ali Muhammed Muavv1z - Âdil Ahmed Abdulmevcûd), Beyrût, 1994, IX, 38.

98 Buhârî, "Buyûu", 43, 44, 45.

99 Karaman, Mukayeseli İslam Hukuku, II, 86.
}

YIL: 6 SAYI: 11 
eder. Taraflar akit meclisinde bulundukları sürece varlığını sürdürür. Îcab ve kabulden sonra tarafların birbirinden bedenen ayrılmaları, yine îcab ve kabulden sonra taraflardan birinin diğerine akdi bozma veya kesinleştirme şıklarından birini tercih etmesi teklifinde bulunması ve karşı tarafın da bunlardan birini tercih etmesi ile sona erer. Taraflar bedenen ayrildiktan sonra akitten rucû etme hakları vardır. Dolayısıyla meclis muhayyerliğini kabul etmişlerdir. ${ }^{100}$

Hanefiler ve İmam Malik (ö. 179) ise, hadisin mecâzî anlamını kabul etmişler ve buradaki ayrılmayı söz ile ayrılma şeklinde anlayarak, meclis muhayyerliğini kabul etmemişlerdir. Dolayısıyla hadisin anlamını "İcab ve kabul tamamlanmadığı" sürece şeklindeki mecâzî manaya hamletmişlerdir. ${ }^{101}$

Yine bir kişinin, “ben şu buğdaydan yemeyeceğim” diye yemin etmesi, fukahânın hakîkât ve mecâz hakkında koymuş olduğu değişik kurallar neticesinde farklı farklı anlaşılmıştır. Ebû Hanîfe yukarıdaki yeminde geçen "buğday” ibaresinin, lafzî manasının anlaşılması gerektiğine vurgu yaparak anlamı hakîkî manasına hamletmiştir. Bunun sonucunda bu kişinin buğday dışında bir şey ya da buğdaydan yapılmış olan ekmeği yemesi durumunda yemininden dönmeyeceğine hükmetmiştir. Zira buğday lafzı adeten buğdayın tanesini ifade etmektedir. Dolayısıyla buğdayın tanesini yerse yemini bozulmuş olur. ${ }^{102}$

Ancak fukahânın bazısına göre burada mecâzın umumiliği söz konusudur. Dolayısıyla buğday veya buğdaydan yapılmış başka bir şeyin yenmesi durumunda yapılan yeminden dönüleceği kabul edilmiştir. Yine aynı şekilde şu nehirden içmeyeceğim diyen birisi oradan bardakla su içmiş olsa yemininden dönmüş olur. Zira bilinen ve amel edilen şey bu ifadeden, mecâzî manası olan nehrin suyunun anlaşılmasıdır. Müsta'mel olunan mecâz hakîkî anlamdan daha evlâdır. ${ }^{103}$

100 İbn Kudâme, el-Muğnî, VI, 11; Şâfîi, Muhammed b. İdrîs, el-Ümm, (tah. Rıf'at Fevzi Abdülmuttalib), yy., 2001, IV, 9.

101 İbn Rüşd, Bidâyetü'l-müçtehîd, II, 142; Molla Hüsrev, Dürerü'l-hükkâm fî şerhi Ğureri'l-ahkâm, İstanbul, 1978, II, 145.

102 Cessâs, el-Fusûl, I, 78-79.

103 İmâm Ebû Yûsuf ve İmâm Muhammed bu konuda Ebû Hanîfe'ye muhalif davranarak mecâzî manayı tercih etmişlerdir. Dolayısıyla kişi, buğdaydan yapılmış ekmeği yerse, yemininden 


\section{$278 \cdot$ YALOVA SOSYAL BILIMLER DERGISI}

Boşanmış olan kadınların iddet sürelerini ifade eden "boşanan kadınlar kendi kendilerine üç kurû' beklerler"'104 ayetinde geçen kurû' lafzı, hakîkî anlamı gereği "hayız hali"ne, mecâzî anlamı gereği de "temizliğe" delâlet eder. Zira bu kavram Arap dilinde her iki manayı da ihtiva eden müşterek bir lafızdır. Hanefî ve Hanbelî ulemaya göre, bir lafzın aynı anda hem mecâz hem de hakîkî anlamı ifade etmesi mümkün olmadığından kurû' lafzının hakîkî anlamı olan "hayız hali"ne hamledilmesi gerekir. Yani boşanmış bir kadın üç defa hayız olduktan sonra iddet süresi sona erer. Dolayısıyla üçüncü defa hayız olan kadın o hayız döneminin bitmesini beklemek zorundadır. Şâfî'lere göre ise, mecâzî manası olan "temizlik süresi” anlaşılmalıdır. Bunun sonucunda kadının üç defa temizlik süresini bitirmesinden sonra iddet süresi sona ermiş olur. Bu durumda kad1nın üçüncü hayızının başlangıcında iddet süresi sona erer. ${ }^{105} \mathrm{Bu}$ farklılık, boşanmış olan kadınların, kocası ölmüş ya da kaybolmuş olan kadınların iddet bekleme süreleri hususundaki hükümlerin temel dayanağını da oluşturmaktadır. ${ }^{106}$

Kinâye kavramı da fikıh ilminde, fukahânın farklı hükümler çıkarmasına sebep olan belâgat terimlerinden birisidir. Kinâye kavramının fikıh ilminde en çok söz konusu olduğu alan "sözlü olarak boşama" konusudur. Boşama lafızlarının sarîh ya da kinayî olması boşanma şeklini değiştireceğinden, bu durum fukahânın farklı hüküm vermesine sebep olmuştur.

Hanefî̀ mezhebine göre, kinâyî sözlerle boşama, ancak niyet ve halin delâletiyle geçerlidir. Meselâ koca karısına "sen bâinsin" dese bu durumda kocanın boşama niyetinin olup olmadığına ya da içinde bulunulan durumun boşamaya delalet edip etmediğine itibar edilir. Zira "bâin" ifadesi "ayrılma" anlamındadır. Ancak bu ayrılma boşama anlamında olabileceği gibi aileden ya da evden ayrılma manasında da kullanılmış olabilir. Dolayısıyla burada boşama olup olmadığını belirleyen, kocanın niyetidir. Koca boşama niyetiyle bu ifadeyi kullandıysa boşama gerçekleşir. Halin delâletinde ise, öfke hali, boşanma işinin konuşulması hali ve rıza hali şeklinde

dönmüş kabul edilir. Cessâs, el-Fusûl, I, 78-79; Şâşi, Usûlü 'ş-şâş̂, s. 49-54.

104 Bakarâ, 2/228.

105 Cessâs, el-Fusûl, I, 46.

106 İslam hukukçularının iddet hususundaki ihtilaflarının geniş bir tahlili için bkz. Karataş, Fatih, “İslam Hukukunda İddet”, Şırnak İlahiyat Fakültesi Dergisi, Şırnak, 2013, c. IV, sy. 8, s. 161-190.

YIL: 6 SAYI: 11 
boşamayı belirleyen üç durumdan bahsedilmektedir. ${ }^{107}$

Malikî mezhebine göre kinayeli ifadeler, açık olan ve kapalı olan şeklinde gruplandırılmıştır. Açık olan kinayeli ifadeler, sarih hükmünde olup niyete ihtiyaç hissettirmez. Kapalı olan kinayeli ifadelerde ise boşamanın meydana gelmesi niyete bağlıdır. Kocanın boşama niyeti yoksa boşanma gerçekleşmez. Ama boşamaya niyet ederse boşama meydana gelir. ${ }^{108} \mathrm{Ka}-$ palı olan kinayeli ifadelerle bir boşamaya niyet edilmişse bir boşama, iki veya üç boşamaya niyet edilmişse niyet edilen sayıda boşama gerçekleşir. ${ }^{109}$

Şafi mezhebine göre, kocanın veya onun yetki verdiği kimsenin niyeti bulunmadıkça kinayeli sözcüklerle boşama meydana gelmez. Burada halin delâletine bakılmaz. Buna göre koca, eşine karşı kinayeli sözcüğü kullandiktan sonra "ben bununla boşamaya niyet etmedim" dese tasdik olunur ve boşamanın yokluğuna hükmolunur. Ayrıca bütün kinayeli ifadelerle, niyet edildiği sayıda boşama gerçekleşir. Birden fazla sayıda boşamaya niyet edilip, boşama sözünü söylerken "bir boşamaya" denilmişse bile niyet edilen sayıda boşama meydana gelir. Mesela bir adam karısına "sen teksin" der ve bununla iki ya da üç boşamaya niyet ederse kadın iki veya üç boşamayla boşanmış olur. Şafiî mezhebine göre kinayeli ifadeler kullanılırsa bain talak değil, ric'î talak meydana gelir. ${ }^{110}$

Görüldüğü üzere kullanılan ifadenin kinâyeli olarak kabul edilmesi halinde boşama şekli hususunda farklı hükme varılmıştır.

Sonuç olarak, sarîh lafız söyleyenin açık iradesini temsil ederken ve söyleyenin niyetinin araştırılmasına ihtiyaç hissettirmezken, kinâyeli lafzın mana ve hükmü ancak niyet veya halin delaleti gibi bir delille sabit olur. Bu karîneler bulunmadıkça ve kinayeli lafzın içerdiği ihtimal ve tereddüt hali ortadan kaldırılmadıkça herhangi bir hüküm ifade etmez.

107 İbn Âbidîn, Muhammed Emîn, Reddü'l-muhtâr ale'd-Dürri'l-muhtâr şerhi tenvîri'l-ebsâr, (tah. Adil Ahmed Abdülmevcud, Ali Muhammed Muavviz), Riyâd, 2003, IV, 528.

108 İbn Rüşd, Bidâyetü'l- Müctehid, II, 62-63; Karâfî, Şihâbüddîn Ebu'l Abbas Ahmed b. İdris, el-Furûk, Beyrut t.y., III, 193; Şınkîtî, Muhammed Şeybânî b. Ebu Ahmed, Tebyînü'l-Mesâlik Şerhu Tedrîbü's -Sâlik ilâ Akrabi'l- Mesâlik, Beyrut, 1995, III, 148-149.

109 Cezîrî, Abdurrahman, Kitabü'l-Fıkh ale'l Mezâhibi'l-Erbaa, Kahire, 1969, IV, 327.

110 Şîrâzî, el-Mühezzeb, IV, 294. 


\section{Sonuç}

Yukarıda ifade edilen bilgiler ışığında, mecâz ve kinâye kavramlarının fikhî hükümlerdeki etkisinin, söz konusu kavramların belâgat ilmindeki anlam çerçevesiyle irtibatlı olduğunu vurgulamalıyı. Diğer bir ifadeyle her iki kavramın manaya delâletinin dilbilimciler tarafından tespitinin dikkate alınması zorunludur. Zirâ dilcilerin bu kavramları farklı değerlendirdikleri açıktır. Özellikle kinâye kavramı hususunda klasik ve modern dilciler arasında farklı tanımlamalar olduğu görülmektedir. Diğer taraftan usulcüler tarafından yapılan tanımların belâgat ilmindeki tanımlara dayalı olduğu ifade edilebilir. Zaten bir lafzın hakîkî ya da mecâzî anlamda olup olmadığı hususunda dilcilerin kullanımının belirleyici olması, bu durumu ifade etme noktasında yeterlidir.

Fukahânın, ihtilaflı olan konularda farklı hükümlere varmalarının temel sebeplerinden birisi, dini kaynaklarda mecâzî ve kinâyî kavramların bulunmasıdır. Her iki kavramla alakalı tespit ve sınırların tayin edilmesi, güncel meseleler hususunda da önemlidir. Bundan daha da önemli olan etken, her ülkenin dilsel ve örfsel özelliklerinin farklılığıdır. Diğer bir ifadeyle, bir lafzın mecâzî ya da kinâyî manaya hasredilmesi, ilgili bölgenin dil kuralları ve örfü ile ilişkilidir. Bu bağlamda, dilcilerin anlamı netleştirme hususunda birinci basamak olduğunu, fukahânın da buna dayanarak kendi kriterleri çerçevesinde hükme vardığını ifade edebiliriz. Dolayısıyla bir lafzın hükme delâletinde, dilcilerin ve fukahânın ortak müdahalesi söz konusudur.

Sonuç olarak, gerek Arap dilinin yapısı ve dilbilimcilerin kavramın anlamını tespit etmeleri, gerekse de fukahânın bu tespit ışığında o lafza yüklediği anlam, fikhî hükümlerin ihtilafinda önemli oranda rol oynamaktadır.

\section{Kaynakça}

YIL: 6 SAYI: 11 
Akdemir, Hikmet, Belă̆at Terimleri Ansiklopedisi, İzmir, 1999.

Akdemir, Hikmet, “Kur'an-1 Kerîm’de Mecâzın Varlığı Problemi”, Harran Üniversitesi Illahiyat Fakültesi Dergisi, Şanlıurfa, 1998, sy. 4, s. 59-90.

Ali el-Cârim, Mustafa Emin, Belâgatu l-vâzıha, İstanbul, ts..

Bilgegil, M. Kaya, Edebiyat ve Bilgi Teorileri, İstanbul, 1989.

Bolelli, Nusrettin, Belâgat: Arap Edebiyatı Bilgi ve Teorileri, İstanbul, 1993.

Cessâs, Ahmet b. Ali er-Râzî, el-Fusûl fi'l-Usûl, Kuveyt, 1985.

Coşkun, Mendres, "Kinâyenin Belâgât Kitaplarındaki Seyri ve Onu Yeniden Anlama ve Sunma Denemesi, Bi்LIG, 2008, sy. 44, s. 63-88.

Cürcânî, Abdulkahir, Delâilü'l-i 'caz, Dımeşk 1987.

Cürcânî, Mu'cemu't-ta'rifât, (tah. Muhammed Siddîk el-Minşâvî), Kâhire, ts..

Dönmez, İbrahim Kafi, “Beyân”, DİA, 1992, VI.

Durmuş, İsmail, "Mecâz", DIA, 2003, XXVIII.

Gazâlî, Muhammed b. Muhammed, el-Mustasfâ min İlmi’l Usûl, Mısır, 1322.

Görmez, Mehmet, Sünnet ve Hadisin Anlaşılmasında Yöntem ve Metedoloji Sorunu, Ankara, 2000.

Hâşimî, es-Seyyid Ahmed, Cevahiru'l- belağa fi'l-meani ve'l- beyan ve'l-bedi', (tah. Yûsuf es-Samîlî), Beyrut, ts..

İbn Âbidîn, Muhammed Emîn, Reddü'l-muhtâr ale'd-Dürri'l-muhtâr şerhi tenvîri'l-ebsâr, (tah. Adil Ahmed Abdülmevcud, Ali Muhammed Muavviz), Riyâd, 2003.

İbn Cellâb, Hüseyn b. Hasan, et-Tefrî̀, (tah. Hüseyn b. Sâlim ed-Dehmânî), Beyrût, 1987.

İbnü'l-Hümâm, et-Tahrîr, ( İbn Emîru Hâc, et-Takrîr ve’t-tahbîr içinde), Bulak 1316.

İbn Kudâme, Ebû Muhammed Muvaffakuddin Abdullah b. Ahmed b. Muhammed, el-Muğnî, (tah. Abdullah b. Abdulmuhsin et-Türkî, Abdullfettah Muhammed el-Hulv), Kâhire, 1982.

İbn Rüşd, Ebu'l Velid Muhammed b. Ahmed, Bidâyetü'l- Müctehid ve Nihâyetü'l-Muktesı, İstanbul, 1985. 
- YALOVA SOSYAL BíLIMLER DERGisi

Kablan, Süleyman, Arap dili ve Belâgatında Mecaz-ı Mürsel ve Alakaları (Yüksek Lisans Tezi), İstanbul, 2006.

Karâfî, Şihâbüddîn Ebu'l Abbas Ahmed b. İdris, el- Furûk, Beyrut, ts..

Karaman, Hayrettin, Mukayeseli İslam Hukuku, İstanbul, 1991.

Karataş, Fatih, “İslam Hukukunda İddet”, Şırnak Illahiyat Fakültesi Dergisi, Şırnak 2013, c. IV, sy. 8.

Kâsânî, Alauddin Ebibekr b. Mes'ud, Bedaiu's-Sanâi fì Tertîbi 'ş-Şerât, Misır, 1910.

Kazvînî, Hatîp, el-Îzâh fî 'ulûmi’l-belâga, (nşr. İbrâhîm Şemsüddîn), Beyrut, 2003.

Koca, Ferhat, "Kinaye", DIA, 2002, XXVI.

Koca, Ferhat, "Mecaz”, DİA, 2002, XXVI.

Mâverdî, Ebu'l-Hasen Ali b. Muhammed, el-Hâvî fî fikhi 'ş-Şâfî, Dâru'l-Kütübi'l-İlmiyye, (tah. Ali Muhammed Muavviz - Âdil Ahmed Abdulmevcûd), Beyrut, 1994.

Mecelle-i Ahkâm-ı Adliye, Hikmet Yayınları, İstanbul, 1985.

Molla Cîven, Ebî Sa'id, Nûru'l-envâr ale 'l-menâr, İstanbul, 1986.

Molla Hüsrev, Dürerü'l-hükkâm fî şerhi Ğureri'l-ahkâm, İstanbul, 1978.

Mut'inî, Abdulazim İbrahim, el-Mecaz fi'l-luğa ve'l-Kur'âni'l-Kerim, Kâhire, ts..

Müftüoğlu, Nasrullah, "Beyân”, DİA, 1992, VI.

Nesefî, Ebulberekât, Keşfu'l-esrâr şerhu'l-musannifi ale 'l-menâr, İstanbul, 1986.

Nevevî, Kitâbu'l-Mecmû' şerhu'l-Mühezzeb li 'ş-Şîrâzî, (thk. Muhammed Necîb el-Mutî̀'̂̀), Cidde, ts..

Özdemir, İbrahim, İslam Düşüncesinde Dil ve Varlık, İstanbul, 2006.

Râzî, Fahreddîn b. Muhammed, el-Mahsûl fi i'lmi'l-Usuli'l-fikh, Beyrut, 1992.

Serahsî, Ebû Bekr Muhammed b. Ahmed, Usûlu’s-Serahsî, Beyrut, 1973. Kitabu'l-Mebsut, Lübnan, 1989.

Sekkâkî, Ebû Yâkub, Miftâhu’l-Ulûm, Beyrût, 2000.

YIL: 6 SAYI: 11 
BELÂGAT ILMINDEKI MECÂZ-KINÂYE KAVRAMLARININ FIKHÎ HÜKÜMLERE ETKISİ • 283

Soysal, M. Orhan, Edebi Sanatlar ve Tanınması, Ankara,1992.

Şâfî̂, Muhammed b. İdrîs, el-Ümm, (thk. Rıf'at Fevzi Abdülmuttalib), yy., 2001.

Şâşî, Nizâmuddîn, Usûlü' 'ş-şâ̧şî, Beyrût, 2000.

Şensoy, Sedat, "Belâgat Geleneğinde Aklî Mecâz Tartışmaları”, İslâm Araştırmalar1 Dergisi, sy. 8, 2002.

Şevkânî, Muhammed b. Ali, İrşâdu'l-Fuhûl, (thk. Ebi'l-Hafs Sami b.El-Arabi), Riyad, 2000.

Neylu'l-Evtâr ġerhu Munteka'l-Ahbâr, Beyrut, 1973.

Şınkîtî, Muhammed Şeybânî b. Ebu Ahmed, Tebyînü'l-Mesâlik Şerhu Tedrîbü's -Sâlik ilâ Akrabi’l-Mesâlik, Beyrut, 1995.

Şirazî, Ebû İshak İbrahim b. Ali b. Yusuf el-Firuzabâdî, el-Mühezzeb fî fikhi'l-İmâmi'ş-Şâfî̀, (tah. Muhammed Zuhaylî), Beyrût, 1996.

Tahâvî, Ebû Cafer, Şerhu Me‘âni’1-Âsâr, (thk. İbrahim Şemsuddîn), Dâru'l-Kütübi'l-İlmiyye, I-IV, Beyrut, 2001.

Tavîle, Abdulvehhâb Abdusselâm, Eseru'l-luga fỉ ihtilâfi l-müctehidîn, Misır, ts.. 